\title{
Strong Antiviral Activity of Heated and Hydrated Dolomite -Preliminary Investigation
}

\author{
Hideaki YAMANA ${ }^{1,4)}$, Hiroshi ITO ${ }^{2,3)}$, Toshihiro ITO2,3), Toshiyuki MURASE ${ }^{1,3)}$, Koichi MOTOIKE ${ }^{4)}$, \\ Kazuo WAKABAYASHI ${ }^{4)}$ and Koichi OTSUKI ${ }^{3,5) *}$ \\ ${ }^{1)}$ Departments of Veterinary Microbiology, ${ }^{2)}$ Veterinary Public Health and ${ }^{3)}$ The Avian Zoonosis Research Centre, Faculty of Agriculture, \\ Tottori University, Koyama, Tottori 680-8553, ${ }^{4}$ Mochigase Electric Equipment Co. Ltd., 7-2 Mochigase, Tottori 689-1201 and ${ }^{5)}$ Avian \\ Influenza Research Centre,Kyoto-Sangyo University, Kamigamo Motoyama, Kita-ku, Kyoto 603-8555, Japan
}

(Received 3 July 2006/Accepted 1 November 2006)

ABSTRACT. Heated and hydrated naturally occurring dolomite showed very strong antiviral activity. Infectivity of avian and human influenza, avian infectious bronchitis (coronavirus), Newcastle disease (paramyxovirus) and avian laryngotracheitis (herpesvirus) viruses dropped at least 1,000 fold following contact with the dolomite for five minutes at $4{ }^{\circ} \mathrm{C}$. Dolomite is expected to be useful to inhibit the incidence of emerging and re-emerging infectious diseases.

KEY WORDS: antiviral activity, dolomite, influenza virus.

Outbreaks of SARS (severe acute respiratory syndrome) caused by a coronavirus, and highly pathogenic avian influenza (HPAI), caused by H5N1 virus, have caused big economical and social threats throughout the world since 2003. However, although the threat of the emergence of a pandemic caused by a new type of influenza virus is very great, the subtype of such a new influenza virus is not yet known. Development of an effective new influenza vaccine is therefore difficult. At the present time, it seems to be impossible to prepare a large amount of effective medicine against influenza before a new pandemic occurs. Thus it is very important to develop other possible methods to reduce spread of the virus other than vaccination or medication.

We have succeeded in developing a new material that has very strong bacteriocidal activity [6]. This material is a natural mineral and is called dolomite. The main composition of dolomite is double salt $\mathrm{CaCO}_{3}$ and $\mathrm{MgCO}_{3}$, and a few kinds of inorganic matter [5]. Prior to use dolomite was heated at about $1,000^{\circ} \mathrm{C}$ for $30 \mathrm{~min}$, water was added to the dolomite and finally this material was ground in $\mathrm{nm}$ size. We found that this material has also strong virucidal activity to several types of viruses. Slaked lime has been also known to have some anti-microbiological activity. The main composition of slaked lime is $\mathrm{CaO}$ and duration of its antimicrobiological activity is very short.

A dolomite suspension was prepared as follows: the dolomite available in Tochigi prefecture was calcined at $1,000^{\circ} \mathrm{C}$ for $3 \mathrm{hr}$, water was added to the dolomite and finally ground to $0.75 \mu \mathrm{m}$ diameter using an agitator mill. This processed dolomite was suspended in water to prepare a final $12 \%$ concentration of the suspension.

The viruses tested in this investigation were avian infectious bronchitis virus strain Beaudette 42 (family Coro-

\footnotetext{
* Correspondence to: Otsuki, K., Avian Influenza Research Centre, Kyoto-Sangyo University, Kamigamo Motoyama, Kitaku, Kyoto 603-8555, Japan.
}

naviridae), two strains of influenza virus A/whistiling swan/ Shimane/499/83 (H5N3) and A/Aichi/268 (H3N2) (family Orthomyxoviridae), Newcastle disease virus strain La Sota (family Paramyxovoridae) and avian laryngotracheitis virus strain CE (family Herpesviridae). These strains except avian laryngotracheitis virus had been grown in the allantoic cavity of 10-day-old embryonated SPF hen's eggs for 3 days at $37^{\circ} \mathrm{C}$ prior to being tested; avian laryngotracheitis virus was grown on the chorioallantoic membrane of 12-day-old eggs [2]. Viruses were titrated by the methods described previously $[2,3]$.

Antiviral activity of the processed dolomite was investigated as follows: $0.9 \mathrm{~m} l$ of each viral medium was poured into two small tubes. Then $0.1 \mathrm{~m} l$ of processed dolomite suspension was put into one of these small tubes and the same amount of phosphate buffered saline solution (PBS) ( $\mathrm{pH7}$ 7) was put into the remaining tube and shaken well. These tubes were put into chilled water at $4^{\circ} \mathrm{C}$ and shaken carefully for one, five or $10 \mathrm{~min}$. Then effect of the dolomite was eliminated by ten-time dilution with PBS and then the virus titration was done very quickly (3). The virus titre was calculated by the method of Reed and Muench [4].

As shown in Table 1, the infectivity titre of all strains of influenza, infectious bronchitis and Newcastle disease viruses fell sharply to less than $1: 10,000$ following contact with at least $0.6 \%$ volume of processed dolomite for $10 \mathrm{~min}$ at $4{ }^{\circ} \mathrm{C}$. Infectivity of avian laryngotracheitis virus was detected completely lost following exposure to $0.6 \%$ volume of the dolomite for $10 \mathrm{~min}$ at $4{ }^{\circ} \mathrm{C}$ (data not shown). We repeated this investigation in the same condition and got almost same results.

The antiviral activity of $0.6 \%$ of processed dolomite was then compared for four virus strains. As shown in Fig. 1, avian infectious bronchitis virus did not survive 1 minute's contact with the dolomite. The infectivity titre of both strains of influenza virus fell less than 1:1,000 in five min; 
Table 1. Antiviral activity of treated dolomite

\begin{tabular}{lccccc}
\hline Viruses & $0 \%{ }^{\mathrm{a})}$ & $0.1 \%$ & $0.3 \%$ & $0.6 \%$ & $1.2 \%$ \\
\hline $\begin{array}{l}\text { Avian influenza virus } \\
\text { A/whistling swan/Shimane /499(H5N3) }\end{array}$ & $7.50^{\mathrm{b})}$ & $\geq 7.50$ & 5.50 & 3.50 & 3.50 \\
$\begin{array}{l}\text { Human influenza virus } \\
\text { A/Aichi/2/68 (H3N2) }\end{array}$ & 8.50 & $\geq 8.50$ & N.D. & 3.50 & 3.75 \\
$\begin{array}{l}\text { Avian Infectious Bronchitis Virus } \\
\text { Strain Beaudette 42 }\end{array}$ & 7.75 & 5.50 & N.D. & $\leq 1.50$ & N.D. \\
$\begin{array}{l}\text { Newcastle disease virus } \\
\text { Strain La Sota }\end{array}$ & 8.75 & 8.75 & N.D. & 4.25 & N.D. \\
\hline
\end{tabular}

a) Concentration of treated dolomite. A mixture of processed dolomite and the virus. Containing medium was incubated for $10 \mathrm{~min}$ at $4^{\circ} \mathrm{C}$.

b) $\log _{10} \mathrm{EID}_{50} / 0.2 \mathrm{ml}$.

N.D.: Not done.

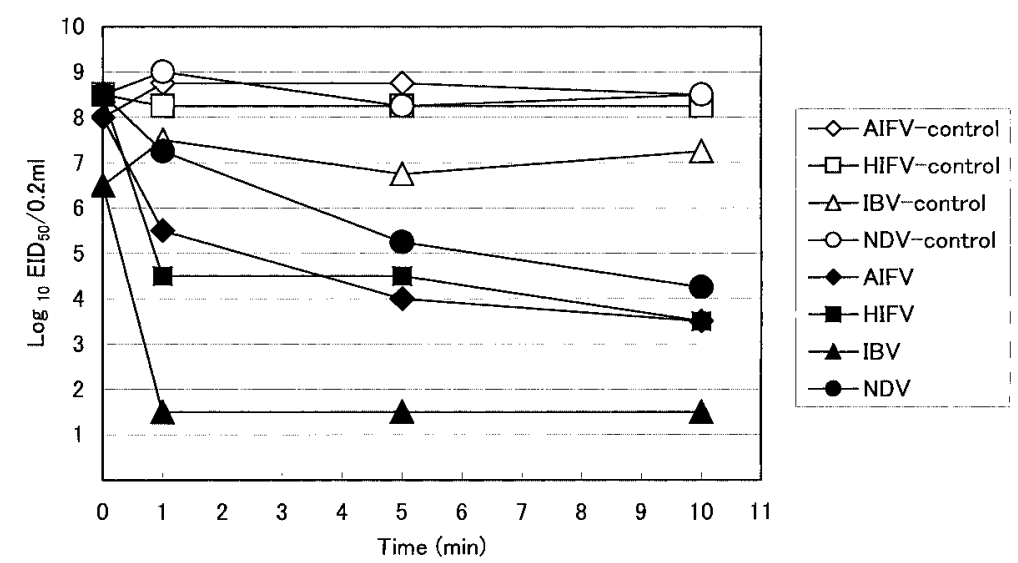

Fig. 1. Antiviral activity of processed dolomite (2). The concentration of processed dolomite used was $0.6 \%$. Incubation was carried out at $4^{\circ} \mathrm{C}$. Avian influenza virus A/whisthing swan/Shimane/499/83 (H5N3) (AIFV), human influenza virus A/ Aichi/2/68 (H3N2) (HIFV), avian infectious bronchitis virus strain Beaudette 42 strain (IBV), Newcastle disease virus strain La Sota (NDV) were tested.

and it took $10 \mathrm{~min}$ for the infective titre of Newcastle disease virus to fall to less than $1: 10,000$. We repeated this investigation in the same condition and got almost same results.

This investigation suggested that heated and hydrated dolomite has not only strong and quick bacteriocidal activity [6] but also a virucidal one. Although all the viruses tested in this investigation have an envelope, the dolomite did not necessarily show the same level of activity against all viruses. Avian infectious bronchitis virus, family Coronavidae showed very strong sensitivity to treatment with the dolomite; avian and human influenza viruses also had considerable sensitivity. It is expected that dolomite can be developed as a useful material against infection with SARS virus, family Coronavidae and a new pandemic caused by a new type of influenza virus.

Naturally occurring dolomite mainly consists of a double salt of calcium carbonate $\left(\mathrm{CaCO}_{3}\right)$ and magnesium carbonate $\left(\mathrm{MgCO}_{3}\right)$ and its safety has already been confirmed [5].
We are now attempting to clarify the mechanisms of the antiviral activity of processed dolomite. Original dolomite has no anti-microbiological activity. Sawai et al. [5] have already suggested that the processed dolomite produces active oxygen species and this may result in the death of microorganisms. Hayakawa et al. (Faculty of Technology, Tottori University) also suggested this possibility (personal communication). We are in the processing of attempting to confirm this and clarify the details of anti-microbiological activity. Since the viruses in contact with the dolomite lost their infectivity very quickly (Fig. 1), this material may destroy the envelope of the virus. We are also in the progress of analyzing this point using non-enveloped viruses.

ACKNOWLEDGEMENTS. Authors wish to thank Dr Jane K. A. Cook, an editor of Avian Pathology, for useful discussion. This study is supported by the Research Program on the Development of Innovative Technology of the Japan 
Science and Technology Agency.

\section{REFERENCES}

1. Dollimore, D., Samtani, M. and Alexander, K. S. 2002. Thermochimica Acta 392-393: 135-145.

2. Guy, J. S. and Bagust, T. J. 2003. pp. 121-134. In: Disease of Poultry. 11 th ed. (Saif, Y. M. ed.), Iowa State Press, Ames, Iowa.
3. Otsuki, K., Yamazaki, K., Kawaoka, Y. and Tsubokura, M. 1988. Vet. Microbiol. 18: 357-362.

4. Reed, L. J. and Muench, H. 1938. Am. J. Hyg. 27: 493-497.

5. Sawai, J., Himizu, K. and Masamoto, O. 2005. Soil Biol. Biochem. 37: 1484-1489.

6. Yamana. H., Otsuki. K., Ito. H., Ito. T., Murase. T., Wakabayashi. K. and Miyoshi. N. 2005. J. Vet. Med. Assoc. 58: 201204. 